\title{
Variations on a Theme: Party Manifesto Discourses in the uk 2010 Election
}

RUTH BREEZE

UNIVERSIDAD DE NAVARRA

ABstRact: The British General Election of 2010 raised high expectations due to the social and political situation of the country, both externally and internally alike: the global economic crisis, the troops in Afghanistan, the anticipation of a political landslide with the accession of the Liberal Democrats to power. However, it seems apparent that the parties involved did not live up to them in terms of political debate and engament with the issues. This article sets out to explore the discourses of the manifestos published by the three main parties, with a view to identifying differences in their means of relating to the electorate, and tracing their discursive construction of key issues.

Keywords: British General Election 2010, party manifestoes, discourse analysis, multimodality, political discourse.

RESUMEN: las elecciones generales británicas de 2010 crearon un alto grado de expectación debido a la situación socio-política del país. Tanto a nivel externo como interno: la crisis económica global, las tropas en Afganistán, la posibilidad real de un cambio en los equilibrios de poder con la entrada de los liberaldemócratas en el gobierno. Sin embargo, los partidos políticos no satisficieron tales expectativas en relación con el nivel del debate político y su respuesta a los temas candentes. Este artículo explora las prácticas discursivas de los programas electorales publicados por los tres partidos principales con el propósito de identificar las posibles diferencias en la construcción discursiva de los temas más relevantes y sus estrategias para conectar con el electorado.

Palabras clave: elecciones generales británicas de 2010, programas electorales, análisis del discurso, multimodalidad, discurso político. 


\section{Introduction}

The British general election of 2010 was characterised by a feeling that change was in the air. The Labour party seemed to have lost its grip on the electorate after 13 years, the Conservative party was rising in public estimation under a new leader, and the Liberal Democrats were at their most optimistic for decades. However, many commentators also felt that the election campaign contained surprisingly few issues: in fact, the different parties were not proposing dramatically different solutions to major problems such as political corruption or the financial crisis, and there seemed to be a broad consensus on issues such as the British presence in Afghanistan. In view of this situation, this article sets out to explore the discourses of the manifestos published by the three main parties, with a view to identifying differences in their means of relating to the electorate, and tracing their discursive construction of key issues.

It has been argued that a crucial, though unclear, relationship between politics and discourse is perceptible at almost every level of public life (Chilton, 2004: 14). One site at which one would expect this association to be at its most obvious is in the party manifesto, which is both an open, public statement of the party's ideas and proposed policies, and a concrete embodiment of the party's construction of itself, its relations to other agents, and its interaction with the context as a whole (Fairclough, 2001). Despite the fact that campaign websites and networking systems have gained increasing importance in recent years (Serfaty, 2010), the election manifesto still constitutes the statement par excellence of the way a party chooses to represent itself to the public (Richards, 2001). Although election manifestos may no longer be the key element in political campaigning, they are still of vital importance in setting the tone of the campaign and defining the battleground on which the fight will be won or lost (Richards, 2001: 155).

In fact, electoral discourse is of particular interest, because real power is at stake, and the different political parties have to engage with currents of popular opinion in order to sense what may be feasible and to send messages that will help to further their ends. Theoretical approaches to this concur in stressing the importance of discourse in the construction of knowledge, but differ in their evaluation of this phenomenon as it is practised in our society. In a Habermasian epistemology, the discourses current in a particular society constitute a form of intersubjective rationality, a kind of coordination of human thought achieved through the exchange of utterances (Habermas, 1981). In this view, rational human truth can come about through sharing, testing and revising ideas in an atmosphere of tolerance and cooperation. However, it has been pointed out that this may be an over-optimistic view of socio-political life. Language use is inherently ambivalent, hence its political potential (Chilton and Schäffner, 
2002). Through discourse, particular world views are constructed and perpetuated, and those who exert control over the discourse may determine what can be said in the public sphere and who can say it (Foucault, 1972). In this context, critical linguists have proposed that discourse analysis could provide a useful tool for exposing ideological manipulation (Wodak, 1996), or, in a more neutral vein, for registering movements that take place under the surface of public life (Stubbs, 1997).

In the context of British political life, discourse analysts have documented developments in political language that reflect ongoing changes in political life, from the populist, heavily ideological discourses of Thatcherism (Fairclough, 1985), to the subtler «product positioning» of the Mandelson era (Chouliaraki and Fairclough, 1999). It has been noted that there is an increasing move towards the marketisation of political discourse, as parties adopt advertising and marketing techniques to «sell» their «brand» (Lloyd, 2006; Ormrod and Henneberg, 2006). However, so far no in-depth study of the propaganda produced for the 2010 election has been conducted in order to map out the most recent developments in this area.

\section{Methodology}

This study takes as its object the manifestos published by the three main political parties in the United Kingdom, namely the Labour, Liberal Democrat and Conservative parties, prior to the general election of May 2010. In methodological terms, this paper takes a discourse analytical approach, seeking to make explicit the ways in which political ideology embedded in and propagated through discourse (Chilton and Schäffner, 2002). In order to ensure that the texts are analysed as carefully and rigorously as possible, the main principles of the balanced approach outlined by Verschueren (2011) will be adopted. Verschueren sets out from the position that discourse-based studies of ideological processes usually start from intuitions arising out of the researcher's own involvement in social issues, which, though inevitable, may lay such investigations open to bias. Researchers are thus under an obligation to base their attempts at answering the initial research question on empirical evidence. Moreover, aspects of meaning should emerge coherently from the data in a recognisable way, and any inconsistencies should be addressed rigorously rather than swept aside. Verschueren (2011) states that discourse research must allow interpretation with proper regard for what can be intersubjectively established to constitute evidence, and although it may be necessary to focus on detail, the researcher should endeavour not to lose sight of the broad picture. To achieve this, he recommends analysts to become thoroughly familiar with their data and 
its immediate and wider contexts, and to pose the question as to how the discourse carves out lines of vision in the world to which it refers. Against this background, it is possible to enquire into relational aspects, deixis, codes, styles, sentence-level features, coherence, tropes, metaphor and so on, to trace the dynamics of how meaning is generated in relation to social structures, processes and relations (Verschueren, 2011). However, before drawing conclusions, the researcher needs to ask whether the assembled findings can be seen to form an identifiable pattern of meaning (Verschueren, 2011), in other words, whether the parts add up to a consistent whole within the pragmatic context of the discourse under scrutiny. Without going into detail, it can fairly be said that Verschueren's account of discourse analysis differs in at least two ways from that proposed by Fairclough $(1985,2001)$. First, the initial diagnosis does not necessarily need to focus on a problem as such (Fairclough, 2001: 236), but rather on an area of interest; and secondly, Verschueren places a heavy emphasis on perspective, which requires findings to be tested against the broader pragmatic context before final conclusions can be drawn.

With these principles in mind, the manifestos will first be considered as a whole: the pre-election context is briefly described, and the main lines of vision carved out by the different parties are identified. The macrostructure of the texts is discussed, and the multimodal aspects of the documents are explored. Since it is not possible to focus in equal detail on every aspect of the manifestos, the subsequent parts of this article centre on two dimenions that emerge as significant in the general overview: the way the manifestos relate to their readers, and their handling of key electoral issues. In the second section, the relational elements in the texts are thus examined, including the use of interactional elements such as rhetorical questions and imperatives, and the subject positions offered to readers. This section includes an investigation of the language codes used, particularly in terms of the way they project distance or closeness. The third section focuses on what were arguably the two most salient issues in the 2010 election: the financial crisis and the recent outbreak of political scandals. The discourses surrounding these topics in the three manifestos are explored, including examination of the lexical choices made and the use of metaphors. Finally, conclusions are drawn as to the similarities and differences between the three manifestos, and some explanations are offered concerning developments in political discourse in the era of globalisation. 


\section{General Overview}

\subsection{Background}

The political scenario in Britain before the election in May 2010 was characterised by uncertainty. Although Labour's popularity had waned, neither of the other two parties seemed to have a clear lead. Opinion polls wavered as to the likely outcome. Apart from the personal qualities of the party leaders, the contested issues in the electoral campaign centred on the recession, on the recent political expenses scandals, and on questions related to public spending. Other topics, such as support for troops in Afghanistan or environmental awareness, though acknowledged as important, did not emerge as sites of struggle. Regarding the attitude and expectations of each party, it is fair to say that for Conservatives, the chance of winning an election for the first time since 1992 seemed tantalizingly close. For Labour, despite Brown's lack of charisma, there still seemed to be some chance of a return to power, albeit with a reduced majority and possible coalition with the Liberal Democrats. However, it was probably the Liberal Democrats who were most optimistic, since the likelihood of a three-way split meant that they would be close to power for the first time in almost a century, and if they could gain sufficient leverage, they might be able to achieve their goal of electoral reform, thereby ensuring a secure foothold in the British politics of the future.

In 2010, the manifestos published by the three main UK parties can be seen to project the principal issues in different ways. Labour's discourses construct Britain as the victim of a global crisis, which is emerging thanks to Labour's efforts. The Conservative manifesto attributes blame for economic problems to Labour's mismanagement of the economy. The Liberal Democrats locate responsibility for the crisis with politicians and big business in general, and the two-party system in particular. As far as political scandals are concerned, the two major parties both seek to distance themselves from responsibility: Labour by likening the expenses scandal to the global financial crisis, both of which are constructed as «seismic events», and Conservative by attributing responsibility to «politicians», and thereby obscuring their own part in the problem. The Liberal Democrats trace responsibility back to the nature of the electoral system, finding yet another argument in favour of proportional representation.

\subsection{Structure}

The Labour manifesto is divided into three parts, «rebuilding our economy», «protecting public services and strengthening society», and what it 
terms «a new politics». Each of these has subsections covering the major election issues. It concludes with a 50-point agenda for «a future fair for all» which is colour-coded to link the points to different themes. The Liberal Democrat manifesto is organised discursively around the reader: a straightforward contents page lists sections such as «your money» and «your life». In line with the party's commitment to environmental issues, the various subsections of the manifesto that relate to the environment are specially coded with green tabs. The document ends with several pages of detailed financial data to explain the party's proposals concerning taxation, spending and saving. The Conservative manifesto is divided into three main parts, headed by imperatives: «change the economy», «change society» and «change politics», which are subdivided into sections with bullet-point-type headings (e.g. «encourage enterprise»). The sections are interspersed with striking full-page photographs or graphics which have a tangential relationship to the surrounding text.

\subsection{Multimodal Aspects}

Meaning is made in different ways, and although language constitutes the main focus of this study, it is impossible to ignore the other semiotic resources which contribute to the overall message (Kress and van Leeuwen, 2001). In terms of design and image, the three manifestos present a study in contrasts. Internally, Labour's manifesto (78 pp.) could be characterised as signifying austerity, with no photography, and only monochrome naif images to head each section. The multicoloured cover, which links with the rainbow scheme of the contents page, shows a stylised view of a family looking into a sunrise (or sunset) framed by two horizontal red blocks, which was described by one commentator as «1950s Soviet chic» (Glancey, 2010). The Liberal Democrat manifesto (112 pp.) is designed around a four-colour scheme (two shades of blue, green and orange), and these colours are used to organise the thematic sections of the text. It includes large photographs, most of which are of party leader Nick Clegg himself in different situations - visiting a school, a library, posing with other politicians - conveying the inescapable message that Clegg is the face of Liberal Democracy. Use of the leader in «branding» the party for election purposes reflects long-term tendencies in the United States which are becoming increasingly common elsewhere (Harris, 2001; Lloyd, 2006). Some photographs also include members of ethnic minorities or show everyday situations such as shopping in a supermarket, and the general idea seems to be to appeal to the average citizen, the person in the street, in a relationship of equality. Finally, the Conservative manifesto (130 pp.) has a sombre cover, described by one journalist as being reminiscent of an old-fashioned hymn-book 
(Glancey, 2010), bearing the title «Invitation to join the government of Britain». Inside, it turns out to be a longer, glossier document reminiscent of the annual illustrated reviews produced by major corporations, with a considerable number of full-page photographs, each chosen to reflect a different, upbeat aspect of the Conservative agenda. Some of the connections here are complex: for example, a glossy photograph of brilliantly-lit glass buildings forms the background to an explanation of Japan's achievements in the green technology market, which put it far ahead of Britain. It can be supposed that the images themselves were chosen to contribute an air of glamour, modernity and prosperity to the manifesto, and that any thematic associations with the text may be somewhat loose in nature. The captions to the photographs can be seen rather as variations on a theme, contributing to the overall message of the manifesto either by positive reinforcement of the main messages, or tangentially, by showing what has been achieved elsewhere (and by implication, could be attained in Britain under good government).

In short, despite some contradictory evidence, the visual semiotics of the manifestos chiefly suggests an intention to convey sobriety, perhaps in keeping with the recession. The Conservative manifesto combines seriousness with complex, suggestive images, while the other two manifestos are notable for their visual simplicity.

\subsection{General Patterns}

In line with Verschueren's principles outlined above, the patterns which emerged from this «first reading» of the manifestos were examined to identify aspects of the manifestos which would bear further investigation. In particular, the contrasts in overall organisation, style and multimodal presentation seemed to highlight differences in the discursive construction of relations with the reader/electorate, while in terms of contents, it was notable that the discourses surrounding two specific issues (the financial crisis and the recent political expenses scandal) differed across the three documents. These intuitions form the starting point for sections 4 and 5 below.

\section{Relation and Interaction}

The construction of interpersonal relations in political discourse belongs to the essence of political propaganda. In a Bakhtinian sense, it could be said that all political discourse is inherently dialogic, designed to relate to and persuade potential supporters (Chilton and Schäffner, 2002). In broad terms, the politician 
has the opportunity to assume or create rapport by identifying with the audience, to address them directly by making promises, or to set up oppositional relations between the audience and some third party. Deictic devices of a personal, social, temporal, spatial or discursive type may all be used to project group identity, signal or create a sense of solidarity, identify insiders and outsiders, locate people and places as «near» or «far», place events along a timescale, etc. (Chilton and Schäffner, 2002). The concept of the «deictic centre» (Verschueren, 1999: 20; Chilton, 2004: 58) is of particular importance to define the point at which discourse is anchored, and from which shared understandings about the nature of society can be built.

Scholars have devoted considerable attention to the use of deictics in political speeches and debate (Wilson, 1990; Blas Arroyo, 2000; Kuo, 2001; Zupnik, 2002; Inigo Mora, 2004; Chilton, 2004; Adetunji, 2006). However, less attention has focused on electoral publications, even though the manifesto is also quite specifically dialogic since it projects a set of relations in which the party usually represents itself as a mainstream group encompassing most of the electorate, whose policies are consonant with that group identity (Reicher and Hopkins, 1996).

Each of the three manifestos analysed here takes a different approach to the construction of relations through personal and social deixis. In this context, the personal foreword signed by each party leader can be identified as establishing a direct relationship of some kind between one individual, the leader, and the readers/electorate. ${ }^{1}$

Brown's foreword begins by using «our» («our troops», «our country») inclusively, to speak on behalf of the British people. At first, he also appears to use «we» inclusively to establish an identity chain («we honour and will always support them»), but by the fourth paragraph, it is clear that «we» refers to the Labour party («we will rebuild the economy») (LPM: 0:2). Confusingly, from here onwards, «our» is sometimes used to refer to the party, but is also still employed in an inclusive sense («our manifesto», but also «our country», «our society»). This blurring of referent, whereby an inclusive «we»/«our» becomes a party «we»/«our», could be seen as a strategy to rope the people/reader into the Labour party agenda, in a «partisan 'we'» of the kind that adept politicians use to assume/create complicity between their party and the public at large (Blas Arroyo, 2000; Fairclough, 2001). Yet the potential benefit of this strategy would seem to be offset by the lack of clarity: the deictic centre is undoubtedly the

1. Although, like most important policy statements, the manifestos are likely to have been the product of considerable team efforts, their respective forewords are signed by the party leader in each case. Ed Miliband is claimed to be the author of the main body of the 2010 Labour manifesto, while Danny Alexander is stated as the author of the Liberal Democrat manifesto. 
Labour party, but no clear relationship is sustained between writer and addressee. Arguably, even the promises or declarations made about what «we» will do appear less convincing, because the object of the action is «our», and so the activity takes on a certain reflexive air: «we will renew our society» (LPM: 0:2), for example, suggests that Labour is going to do something for itself - or society do something for itself -. Only in the concluding lines is a more direct relationship established: «I love Britain and want the very best for our country. This Manifesto is my pledge of a future fair for all» (LPM: 0:2).

The rest of the text can also be found to assume or propose relations between party and electorate. In the introduction, as before, there is some blurring between «we», which usually refers to the party, and «our», which is used indiscriminately to refer to the party or to the people and the country as a whole. Adversarial relations are established between the party and the Conservatives, who are depicted in negative terms («our principal opponents, the Conservatives, offer a fundamentally pessimistic vision of national decline») (LPM: 0:5), perhaps echoing the «negative branding» noted elsewhere in Labour's recent campaign strategies (Lloyd, 2006). In the same key, there is a populist appeal «we speak for the ordinary people of this country who work hard», but the relationship is diffused in the conclusion to this section «we are on their side» (LPM: 0:5). In other sections of the text, «we» is more clearly maintained as meaning the party, although blurring of referent is still found in the case of «our». On the whole, although key sections of the Labour manifesto show attempts at «roping in» the reader through use of inclusive «we» and «our», the rhetorical effect is marred, as in the foreword, by the blurring of «we the people» and «we the party», and by the difficulties in negotiating the identity chain. Direct address is also occasionally used, as in the example from the introduction: «Above all, we need to secure the economic recovery. Get it right and we can go on to build a strong economic future. Get it wrong and we will slip back into recession» (LPM: 0:3). However, this is also mismanaged, because the writer seems to be addressing the people, but in fact, the addressee is the Labour party. Thus although vague deixis is undoubtedly a powerful tool for persuasion in some circumstances (Zupnik, 2002), the 2010 Labour manifesto illustrates how vague deixis with blurring of referents may simply generate confusion. We may speculate that Labour's oddly self-centred discourses show signs of being influenced by what has been described as the «incumbent effect» (Ormrod and Henneberg, 2006: 53): the party in power during the time leading up to the election is affected by a particular need to justify its own deeds, which might make it hard to decentre. Alternatively, the cumulative weight of long years in power may make it hard for the incumbent party to envision powerful new ways of relating to the electorate. 
The Liberal Democrat manifesto takes a radically different approach to establishing relations with the reader. This adopts the risky strategy of addressing the reader directly using «you», a tactic that is evident from the election slogan («change that works for you»), through to the index («your money», «your job»), and throughout the text itself. Clegg begins his foreword «We've had 65 years of Labour and the Conservatives: the same parties taking turns and making the same mistakes, and letting you down» (LDPM: 4). A coherent attempt is made to anchor the discourse in the reader: «you» is offered as the potential deictic centre for much of the text. The first half of Clegg's foreword establishes a three-way relationship between an inclusive «we» (the people in general), «you» (the reader), and some enemies defined variously as Labour and Conservative, banks, corrupt MPs and so on. In the pivotal central section, Clegg then allows his personal voice to dominate, in order to provide a change of direction in the text: «I was brought up to believe that the way things are is not the way they have to be» and addresses the reader directly «So my message for you in this election is simple» (LDPM: 5). The message is then stated in bold type: «Don't settle for low politics and broken promises: be more demanding. Set your sights on the Britain you want for your children and your grandchildren, and use your vote to make it happen.» (LDPM: 5) After this, he launches into a set of promises concerning what the Liberal Democrats are going to do to solve the problem (the party is the subject of six declarations in the next two paragraphs). The conclusion brings together various agents from the rest of the text: «a strong vote for the Liberal Democrats means [...] the end of the stitch-up between the two old parties. It means the beginning of real change that works for you.» (LDPM: 5) Here, the promises (what the Liberal Democrats will do), the enemies (the two old parties) and the reader/electorate (you) are brought together in a strong conclusion.

In the introduction to the manifesto, which follows directly after the foreword, there is extensive use of «we», both inclusively («the problems we face») and to denote the party («we believe»). Again, «those at the top» are constructed as enemies, the vague referent covering both mainstream parties equally. As the text progresses, «we» and «our» become more clearly established as the party, and the reader is again addressed as «you», culminating again in the slogan «change that works for you». In both the foreword and the introduction, relational aspects are used to position the reader (again addressed as «you») among the various agents involved. One further striking point concerning Clegg's foreword is the punchy, demotic tone with heady metaphorical blending. At one point, Clegg declares «Doesn't it make you angry that the banks have been allowed to ride roughshod over our economy, and are still handing out bonuses by the bucket load?» (LDPM: 4) The relationships established are direct, clear, and in terms of social deixis, there is an insistence on intimacy and 
informality, with language that is demotic and forceful: the net effect is that of a «hard sell» which urges the reader to take a stance.

The Conservative manifesto begins with a short text signed by Cameron, courteously entitled, like the manifesto itself, «Invitation to join the government of Britain». This is followed, after the contents page, by a three-page foreword which is not signed, but which is evidently not supposed to be by Cameron, since it refers to him in the third person.

The «Invitation» establishes a theme of «working together», first establishing the need for unity in the face of the country's problems, and then proposing that action should come from the people, working with the Conservative party, in a new form of government. References to «the people», and «our economy», «our social fabric» and «our political system» lead up to the assertion that «we are all in this together». Rhetorically, a bond is established, so that Cameron appears to be speaking on behalf of the people in order to legitimise his proposals. This union is further reinforced in opposition to what «some politicans say», and builds up to the conclusion that «real change comes when the people are inspired and mobilised, when millions of us are fired up to play a part in the nation's future» (CPM: iii). In a staged dialogue with the readers, the writer then declares «Yes, this is ambitious. Yes, it is optimistic» and builds up to a direct appeal using the second person: «all the new measures [...] are just politicians' words without you and your involvement.» (CPM: iii) He then poses three rhetorical questions in the first person plural («how will we...?»), shifting to the first person singular for dramatic effect («unless people [...] start asking 'what can I do?'») (CPM: iii). In this complex dialogue, involving «we» (the party and the people) and «you» and «I» (the reader who is invited to join them and become «one of us»), Cameron's political opponents are constructed as «some politicians», as «this government and its debt», as the enemy of the people which is a bar to progress. Interestingly, Cameron picks up on the electoral theme of corruption in politics in his conclusion, constructing an oppositional relationship between «politicians» and «we»: «Together, we can even make politics and politicians work better. And if we can do that, we can do anything. Yes, together we can do anything.» He ends with a personal appeal in the imperative: «so my invitation today is this: join us, to form a new kind of government for Britain» (CPM: iii).

In short, Cameron's «invitation» builds rhetorical unity between the «people» and his party, sharply defined against «politicians» and «this government», and calls on the reader to join in and «work together». The rhetorical trick seems to work, although it requires suspension of the knowledge that the reader is already one of the people, and Cameron himself is actually a politician. Throughout the text, his discourse is anchored in the party («join us»), and invites the people to be «one of us»: as in previous elections, it can be noted 
that the Conservative electoral discourse is ideologically oriented, anchored in the party and what it stands for, in what has been termed a «leader stance» (Ormrod and Henneberg, 2006: 53).

In relational terms, the anonymous foreword that follows is less complex. It begins with use of inclusive «we» but seamlessly moves over to «we the party», which is working for and with «the people», and is constructed against «Labour» and «Gordon Brown». Here, as throughout the later sections of the manifesto, the Labour-Conservative dichotomy is constantly being reinforced, with explicit mention of both parties' names, following the classic political technique of exploiting a binary conceptualisation (Chilton, 2004: 203). Towards the close of the foreword, an invitation is offered: «Now we ask you to join us [...] so we can offer a better life to all our citizens» (CPM: ix), and this culminates in another appeal to «the people of Britain» to «stick together» (CPM: ix). As before, the main rhetorical force is to persuade the reader to respond positively to the ideological call for responsibility and cooperation, against a background in which the reader has already been «roped in» to the party's point of view and primed against the Labour party. The Conservative manifesto thus uses populist discourses and strong deictic continuities to construct a relationship with the reader that invites him/her to subscribe to its ideological bases.

Contrasts between the three manifestos are therefore to be found in the relationships that are constructed with the electorate, in the way that the discourses are centred deictically, and in the extent to which the party adopts an ideological «leader» stance. Both Labour and Conservative anchor in their parties and attempt to pull the reader over to their side while delegitimizing the other party. However, the effect is stronger and more consistent in the case of the Conservative manifesto, while Labour's discourses bear signs of complacency, perhaps as a result of their long term in office. By contrast, the Liberal Democrats adopt the risky but effective strategy of centring discursively on the reader, claiming to speak and feel for him/her. Conservatives and Liberal Democrats alike make direct, populist appeals to the electorate, but their styles differ. The Conservatives courteously «invite» readers who are constructed as «betrayed» by the current government. Their offer «ropes in» the reader to a virtuous agenda of hard work and responsibility, while Labour is held up as the main public enemy. On the other hand, the Liberal Democrats' readers are projected more aggressively as «angry», and exhorted «not to settle for low politics and broken promises». Although the Liberal Democrats make moves to delegitimise the other two parties, they do so in fairly general terms, probably in the foreknowledge that a coalition is likely. 


\section{Major Issues}

\subsection{The Main Problems Facing the Country}

The discursive construction of key issues is an essential aspect of political rhetoric. In some cases, there may be consensus about the set of terms and discursive parameters that determine the possible discourses surrounding a particular issue (in the 2010 election, Afghanistan appears to have been such a case, since there is scarcely any variation across the three manifestos). In others, what in a cognitive perspective would be termed a «framing contest» may take place (Krebs and Jackson, 2007: 44), in which the parties show disagreement about the terms of debate. In the framework of discourse analysis, such areas are viewed as potential sites of struggle, where competing discourses, often reflecting different ideological concerns, come into juxtaposition in the public sphere (Fairclough, 1985). This is the case in the 2010 manifestos as far as two of the major issues are concerned: the financial crisis and political corruption. In both cases, there is also debate as to what the implications of the situation are, and this is discursively shaped. In each case, two rhetorical questions will have to be answered: first, how are the problems to be understood, and second, what is the party going to do to solve them? This section takes the two main issues of economy and politics in turn, and looks at how those issues are constructed discursively in the manifestos and what implications this may have.

\subsection{The Economic Crisis}

From the portentous statement on the first page - «the world has been rocked by the first great crisis of the new global economic age» (LPM: 0:2) Labour locates responsibility for the economic crisis firmly outside the British political sphere, referring to it variously as a «global crisis» or a «seismic event» (LPM: 0:5, 1:3). Labour portrays its own role in this as having been to rescue Britain's economy from the global situation, and so there is an insistence on «sustaining the recovery» (LPM: 0:4), or «emerging from the crisis» (LPM: 0:6), rather than on implementing a rescue plan. In the introduction, one paragraph is dedicated to justifying what has already been done, and to supporting the idea that these measures are working. Further sections of the manifesto seek to delegitimise the Conservative party by making it responsible for possible future failures («the Tories would threaten recovery with cuts this year») (LPM: 1:3), and elsewhere an attempt is made to polarise matters ideologically in the Labour party's favour: «This is not a conservative moment. It is a progressive moment» (LPM: 0:5). 
Although the Labour manifesto externalises blame for the crisis to «seismic events», and maintains that it has already begun to solve the problem and set the country on the road to recovery, its discourses leave some room for doubt as to whether this optimistic account is valid. At certain points, there are references to «preventing a repeat of the past» (LPM: 0:4) or «forging a new culture of longtermism» (LPM: 0:4) which open up the possibility that errors may have been made, although criticisms are not confronted directly. Most of Labour's promises for securing financial recovery are couched in power-words, so it is frequent to read «create», «build», «encourage», «strengthen», «ensure», «develop», «streamline», «invest», «seize the opportunity», and so on. In this, three adjectives are particularly frequent, enjoying the status of key terms in the discourse of the manifesto: «bold» or «bolder», «fair» or «fairer», and «tough» or «tougher». «Bold» and «bolder» tend to collocate with «reform». «Tough» is used in combination with «choices» («tough choices» occurs 8 times in the section on fiscal policy on LPM: 0:6) and with «decisions», but also occasionally with «reforms». «Fair» is used to describe past or future Labour measures. An attempt is made to legitimise Labour policies by vague references to what «every government of the major developed economies» (LPM: 0:4) is doing. In general terms, Labour uses a panoramic lens to show the crisis facing Britain in as broad a landscape as possible, in order to ward off the potential negative impact on voters that might result from a close-up on the British economy.

Without foregrounding the economic crisis as the main issue, the Liberal Democrats attribute blame for current economic problems to the banks, or more generally to corruption, greed and «power hoarding» by politicians and businesses. Some attention is focused on the consequences of the crisis from the people's point of view, and the subject position of aggrieved citizen is held out to the reader («Doesn't it make you angry that banks have been allowed to ride roughshod over our economy?») (LDPM: 4). Political responsibility is also mentioned, but here the attribution of guilt is generally to the political class, to «government» in general, and in particular to the two-party system. It is striking that although the previous government is indirectly an object of special criticism for its failure to take meaningful action to tackle the financial crisis, no explicit attack is launched on the Blair-Brown administration, possibly as a precautionary measure in view of the possibility of a coalition. Criticism is always levelled more generally at «Labour and Conservative rule», except in one instance, an indictment of the unfairness and complexity of the benefits system, which is attributed specifically to Labour government.

The Liberal Democrats construct their political offer around the focal point of «fairness», asserting that the answer lies in «being honest about the problems that caused the failures» (LDPM: 8 ). Since the problem has been located in a lack of «fairness», the solution that is proposed is to «hard-wire fairness back into 
public life» (LDPM: 8) through structural changes. The principle of «fairness» is to be applied across four broad areas, namely taxation, education, the economy and politics, in order to re-shape public life and build a society in which people have more opportunities, better services and greater participation in democracy. Other than this, there is a rather abstract, visionary air about much of the Liberal Democrat discourse, with its leitmotivs of transformation, innovation, opportunity and sustainability.

The Conservative manifesto is more polarised, laying the blame squarely on the Labour party, and on Gordon Brown in person. One can speculate that Brown's growing unpopularity towards the end of the Labour term made him an easy target for personal attack. It has been observed that party politics seems to be taking an increasingly «personal» turn, as party «branding» relies increasingly on individual figures (Lloyd, 2006: 75). Although this is mainly understood in the positive sense, it is increasingly true that attacks on political parties also draw strength from focusing the issues on the figure of the leader, and thereby «personalising» politics when on the attack, as well as when selling (Coulter, 1998; Lloyd, 2006). The Conservative manifesto tells us roundly in the foreword that «The debt crisis is the terrible legacy that Gordon Brown is bequeathing to our country» (CPM: viii). In later sections dedicated to economic issues, this personal attribution is maintained (e.g. «Gordon Brown's debt, waste and taxes have wrecked the economy» (CPM: 3 )), as is a more general attribution of villainous actions to the Labour party in general («to ensure that no Labour government can ever attempt to bankrupt our public finances again» (CPM: 7)). The debt-fuelled economy is singled out as being the main factor responsible for the crisis, and this is further explained as «irresponsible public spending, an overblown banking sector and unsustainable consumer borrowing on the back of a housing bubble» (CPM: 3), which led to «an age of irresponsibility» (CPM: 3 ).

To solve the problem, the Conservative manifesto weaves a high degree of populist ideology through its critique, advocating a return to «responsibility», in which people «work together». Power words are used («ensure», «build», «create», «reform», «encourage») in what is termed «a bold vision» for the economy. It should be noted that, with the exception of «reform», the range of keywords is identical to that used by Labour. Furthermore, the term «progressive» is made prominent by repetition (CPM: ix). As we have seen, Labour also stakes a claim to being «progressive», attempting to establish a dichotomy between «conservative» and «progressive» near the beginning of the manifesto. Finally, the economic sections of the Conservative manifesto seek to validate Conservative policy with statements by experts, such as Sir James Dyson, which endorse various specific proposals. Although, these proposals are couched in positive terms, they are frequently placed in a dichotomy with Labour policies, which are summarised and refuted throughout the section on the economy. 


\subsection{Political Scandal}

Labour firmly locates political scandal outside the party's locus of control. From the beginning of Brown's foreword, this is attempted through statements such as «the political crisis caused by expenses has undermined the bond of trust between the people and the politicians elected to serve them» (LPM: 0:2). Agency is thus oddly attributed to «expenses», rather than to politicians themselves. The use of passives and grammatical metaphor is highly complex and has been extensively discussed by discourse analysts (van Dijk, 1991; Potter, 1996). Here, however, it would seem clear that this is simply a way of deflecting criticism by locating agency elswhere. A few pages later, in the introduction, political scandal is likened to the global financial crisis: «Just as the global economic crisis was a shock to our economic system; the expenses crisis created turmoil in our political system» (LPM: 0:5). The expenses scandal is thus placed on the level of a second seismic event for which the Labour party need take no responsibility.

In later sections the scandal is taken up again, but now interpreted as meaning that action must be taken to put politics back in touch with people. The solution is within Labour's grasp, it seems: the manifesto promises fundamental reform, with the people's backing. In the special section devoted to politics, the manifesto goes further, declaring that Labour has already «acted swiftly to clean up politics» (LPM: 9:2), and promises more stringent measures to follow. However, it is noticeable that this issue is located as part of a wider theme relating to how «people want a greater say in how this country is governed» (LPM: 9:2), which leads into an array of promises concerning electoral reform, referenda and local government. Although ostensibly this discourse is about giving people greater influence in political life, it is interwoven with an equal and opposite discourse of government power and control, revolving around «extending powers» to the regions, «strengthening the power of Parliament» (LPM: 9:3), giving more power to select committees, and so on. If we follow this twist, the ultimate implications of the crisis in politics, according to Labour, are that politicians need to take the lead and control better what is going on. From 1990s onwards, it was noted that New Labour combined a rhetoric of devolution with a tightening of central control (Fairclough, 2001: 263). The promise of devolution of power and «greater say» is considerably watered down, which is consistent with the top-down, managerial tone of the Labour manifesto noted above.

The foreword to the Liberal Democrat manifesto situates political scandal from the voters' point of view: «Doesn't it make you angry [...] that politics is still the plaything of wealthy donors and corrupt MPs?» (LDPM: 4). One of its four cornerstone policies is entitled «a fair deal by cleaning up politics». The dissatisfaction engendered by references to the expenses scandal is soon 
channelled in a different direction, however. In the first more detailed section on «cleaning up politics» (LDPM: 10), it becomes clear that cleaning up politics will involve reform of the political system, and that this will go via the route of electoral reform, although this is only alluded to rather cryptically as «embracing fair votes for every level of election» (LDPM: 10). In the main section on political reform, the agenda is expressed as being to «put power back where it belongs: into the hands of the people» (LDPM: 87). Again, a link is forged between the «rotten» political system and the need for thorough-going electoral reform. In great measure, this will be achieved through proportional representation, which will eliminate the safe seat and thereby make MPs more accountable. On this issue, the two major parties are identified as the enemy: despite paying lipservice to the idea, they have «worked together to block reform». In short, the Liberal Democrats use the political scandals of the previous year to legitimise their own bid for reform of the political system.

The Conservative manifesto also foregrounds political scandal. As we have seen, Cameron's «invitation» makes the daring move of siding with the people against «politicians», who emerge as an intractable problem that has to be tackled from a position of unity. The foreword refers to the «broken political system» (CPM: ix) (echoing the leitmotiv of the «broken society»), which has to be rebuilt in a spirit of «openness», «transparency» and «responsibility». The section devoted to politics assumes the perspective of «the people of Britain» in expressing «horror» at the revelations which discredited parliament. Rhetorically, the writer again sides with «the public» and «people» against «politicians» and «Westminster politics», claiming that the public has been «shut out for too long» (CPM: 65-66). Moreover, the Conservative party's role in helping to expose the scandals is highlighted, while the Labour party's actions are referred to several times in a negative sense.

As far as the implications are concerned, the section on politics is headed «Make politics more accountable», and begins with the declaration «we will clean up politics». It emphasizes proposals to reform various aspects of parliamentary life, in the name of securing better representation for the people, and promises swift action that will bring about thorough reforms. In its own words, «it will take nothing less than a deep clean of the political system in Westminster to root out the sleaze and dispel suspicion» (CPM: 65). The language is forceful, even violent at times, including phrases such as «allow electors to kick out MPS» (CPM: 66), but notably also includes some phrases that are more commonly associated with a business setting, such as «efficient and effective» and «business plan» (CPM: 67). Although the «managerial» tone is less pronounced here than in the Labour manifesto, it is far from absent: both major parties seem to weave claims to managerial efficiency into the ideological fabric of their discourse, mirroring trends observed elsewhere concerning the 
«managerial» turn of contemporary politics (Chouliaraki and Fairclough, 1999). In the previous election campaign (2005), it was noted that the Labour party adopted a «managerial» and «technocratic» approach to policy development, while the Conservative campaign had a heavier ideological tone and greater emotional appeal (Ormrod and Henneberg, 2006: 51). The material studied here, though different in other respects from the 2005 propaganda, seems to confirm that these tendencies reflect long-term developments in British political discourse.

\section{Conclusions}

In the 2010 UK election campaign, as elsewhere, the three main parties' discourses were heavily conditioned by circumstances and by the constraints of their position on the political landscape. Thus the Liberal Democrat party had to exploit the possibilities of being a «third party» that could at most hope to participate in power-sharing, while insisting on a change in the electoral system that might permit it to enter the real arena. The Labour party's 2010 election discourses were constrained by its record during its long years of power and by the recent scandals and crises, which limited the potential for making credible promises of change. Two of the main rhetorical challenges faced by Labour in its manifesto were that of trying to deflect criticism over the disasters of the previous few years, and that of attempting to promise something new after thirteen years in power. In its strategy of emphasising the «toughness» of the world economic situation, and the need to make «tough choices», the Labour manifesto may have created excessively negative connotations which were unlikely to persuade the electorate. On the other hand, the top-down discourse of state control may be attributable to Labour's traditional preference for «big government», but may also be a product of the fact that the Labour party had held power for so long and therefore tended to talk from a position of power. Finally, the Conservatives, as the main opposition party, seized an obvious opportunity to offer a break with the past, engaging in rhetorical solidarity with the electorate in connection with problems attributable to Labour. Their emotive, more ideologically charged manifesto emphasises the Labour-Conservative dichotomy in order to stress the need for voters to take sides. Moreover, while not underestimating economic or political problems, their manifesto constructs the problems as difficulties that can be overcome with the right leadership, and uses multimodal affordances to convey a confident, upbeat message.

However, it is also striking that certain discourses appear to run through all three manifestos. During the electoral campaign, cynical commentators ran an election blog entitled «spot the difference» which gave vent to a general feeling 
that the parties did not have any strikingly new policies to offer, and this impression is borne out by a quantitative overview of the keywords in the manifestos (Rogers, 2010). ${ }^{2}$ The rhetoric of solidarity with the people is essentially the same across the manifestos, and the key values invoked operate within a similar range. Both Labour and Conservative stake claims to being «progressive». As we have seen, «responsible» and «responsibility» are used in all three brochures, while «tough» also occurs in all of them to refer to the current economic situation and the type of decisions that have to be made.

The differences between them appear to be matters of degree rather than essence, as the Conservative manifesto leans more heavily on the theme of «responsibility» as providing the way out of the crisis, perhaps evoking the «reason and responsibility» catchwords of the Thatcher era, while Labour chooses to place a heavier emphasis on «toughness», perhaps in line with its traditionally grittier image. On the other hand, the Liberal Democrats, while also using both words on occasions, choose to promote their main ideas in terms of «fairness» and «opportunity», words calculated to appeal to middle Britain. This resemblance might be due to the parties' appropriation of each others' discourses, or to their different attempts at colonising the «middle ground» which has become so crucial for electoral purposes (Lilleker et al., 2006). Commentators have pointed out that the lack of substantive, well-understood policy differences and the lowering of ideological tone in recent elections have meant that the main difference between the parties is one of style (Chouliaraki and Fairclough, 1999; Savigny, 2006): as we have seen, the 2010 manifestos each constitute a distinctive offering in this respect, sending different messages through multimodal channels and establishing different relationships with their readers.

The fundamental similarity of the discourses being used is consistent with the growing realisation that party politics in many developed countries in the $21^{\text {st }}$ century is less a question of ideological conflict and more a matter of «spin» and adaptation to electoral market forces (Lilleker et al., 2006; Savigny, 2006; Seidman, 2008). As far as language is concerned, this leads to increasing hybridisation of political and promotional discourse, which might partly account for the similarities observed between manifestos (Fairclough, 1985, 2001; Chouliaraki and Fairclough, 1999). Recent attempts at categorising political parties' ideological tendencies through their manifestos have proved frustrating, leading specialists to conclude that parties make moves to the right or left in order to adjust to changing political conditions and, above all, to remain

1. The same trend had been noted in the campaign running up to the General Election of 2005, described as «generic [...] distinguished by differences in style rather than substantive differences in policy» (Savigny, 2006: 82). 
competitive (Pelizzo, 2003; Franzmann and Kaiser, 2006). It is widely acknowledged that late capitalism has seen growing marketisation of public life (Habermas, 1989), and political parties are viewed as products to be sold to the public rather than vehicles of deep ideological conviction (Ormrod and Henneberg, 2006). This is often the public counterpart of the move to a «managerial» approach to political action behind the scenes (Savigny, 2006). Thus externally, the party is marketed to be attractive to the voters, while internally it is understood as an institution for gaining power and «managing» public affairs. Moreover, commentators have pointed out that the trend towards marketisation is generally accompanied by the aestheticization of political discourse, which distances politics from the commitment to rational argumentation (Best and Kellner, 1991; Chouliaraki and Fairclough, 1999). Although the history of the $20^{\text {th }}$ century may teach us to welcome a lowering of ideological intensity, we should remain wary of the threats posed by a public sphere governed by market forces, since these are increasingly liable to manipulation.

\section{Works Cited}

AdetunJ, A. (2006): «Inclusion and exclusion in political discourse: deixis in Olusegun Obasanjo's speeches», Journal of Language and Linguistics, 5(2): 177-191.

Best, G.; D. Kellner (1991): Postmodern Theory. Critical Interrogations, London, Macmillan.

Blas Arroyo, J. (2000): «Mire usted Sr. González... Personal deixis in Spanish political-electoral debate», Journal of Pragmatics, 32: 1-27.

Chilton, P. (2005): Analysing Political Discourse. Theory and Practice, London, Routledge.

Chilton, P.; C. Schäffner (2002): Politics as Text and Talk, Amsterdam, John Benjamins.

Chouliaraki, L.; N. Fairclough (1999): Discourse in Late Modernity. Rethinking Critical Discourse Analysis, Edinburgh, Edinburgh University Press.

Coulter, A. (1998): High Crimes and Misdemeanours: The Case against Bill Clinton, Washington, Regnery Publishing.

FAirclough, N. (1985): Language and Power, London, Longman.

- (2001): «The discourse of New Labour. Critical discourse analysis» in Wetherell, M.; S. TAYlor; S. Yates (eds.) (2001): Discourse as Data: a Guide for Analysis, London, Sage. 229-266.

Foucault, M. (1972): The Order of Things, London, Tavistock. 
Franzmann, S.; A. KAISER (2006): «Locating political parties in policy space: a reanalysis of party manifesto data», Party Politics, 12: 163-188.

GLANCEY, J. (2010): «Election manifestos: a tale of two covers», The Guardian, 12 April, [accessed 21 July 2010], <http://www.guardian.co.uk/politics/ 2010/apr/12/labour-conservative-election-manifesto-covers $>$.

Habermas, J. (1989): The Structural Transformation of the Public Sphere, Cambridge, Polity Press.

Harris, P. (2001): «To spin or not to spin, that is the question: the emergence of modern political marketing», Marketing Review, 2: 35-53.

Inigo Mora, I. (2004): «On the use of the personal pronoun we in communities», Journal of Language and Politics, 3(1): 27-52.

KREBS, R.; P. JACKSON (2007): «Twisting tongues and twisting arms: the power of political rhetoric», European Journal of International Relations, 13: 35-66.

Kress, G.; T. VAN Leeuwen (2001): Multimodal Discourse. The Modes and Media of Contemporary Communication, London, Hodder Education.

Kuo, S. (2001): «Reported Speech in Chinese Political Discourse», Discourse and Society, 3(2): 181-202.

- (2002): «From solidarity to antagonism: The uses of the second person singular pronoun in Chinese political discourse», Text, 22(1): 29-55.

LILlEKER, D.; N. JACKSON; R. SCULlion (2006): «Introduction» in LILLEKER, D.; N. JACKson; R. Scullion (eds.) (2006): The Marketing of Political Parties. Political Marketing at the 2005 British General Election, Manchester, Manchester University Press.

LLOYD, J. (2006): «The 2005 General Election and the emergence of the 'negative brand'» in Lilleker, D.; N. JACKSON; R. SCullion (eds.) (2006): The Marketing of Political Parties. Political Marketing at the 2005 British General Election, Manchester, Manchester University Press. 1-30.

OrmRod, R.; S. HenNeberg (2006): «Are you thinking what we're thinking?» or «Are we thinking what you're thinking?» An exploratory analysis of the market orientation of the UK parties» in LILLEKER, D.; N. JACKSON; R. Scullion (eds.) (2006): The Marketing of Political Parties. Political Marketing at the 2005 British General Election, Manchester, Manchester University Press. 31-58.

Pelizzo, R. (2003): «Party positions or party direction? An analysis of party manifesto data», West European Politics, 26(2): 67-89.

Potter, J. (1996): Representing Reality: Discourse, Rhetoric and Social Construction, London, Sage.

REICHER, S.; N. Hopkins (1996): «Self-category constructions in political rhetoric: an analysis of Thatcher's and Kinnock's speeches concerning the British miners' strike (1984-5)», European Journal of Social Psychology, 26: 353-371. 
Richards, P. (2001): How to Win an Election. The Art of Political Campaigning, London, Politico's Publishing.

Rogers, S. (2010): «Conservative manifesto: how does it compare to Labour?», The Guardian, 13 April, [accessed 21 July 2010], <http://www.guardian.co.uk/ news/datablog/2010/apr/13/conservative-manifesto-compares-labourwordle>.

SAVIGNY, H. (2006): «Political marketing and the 2005 election: what's ideology got to do with it?» in Lilleker, D.; N. JACKSON; R. Scullion (eds.) (2006): The Marketing of Political Parties. Political Marketing at the 2005 British General Election, Manchester, Manchester University Press. 81-97.

Seidman, S. (2008): Posters, Propaganda and Persuasion in Election Campaigns around the World and through History, New York, Peter Lang.

Serfaty, V. (2010): «Web campaigns: popular culture and politics in the U.S. and French presidential elections», Culture, Language and Representation, 8: 115-129.

VAN DiJK, T. (1991): Racism in the Press, London, Routledge.

- (2002): «Political discourse and political cognition» in Chilton, P.; C. SCHÄFFNER (eds.) (2002: 203-237).

VerSCHUEREN, J. (2011): Ideology in Language Use and Ideology: Pragmatic Guidelines for Research, Cambridge, Cambridge University Press.

Wilson, J. (1990): Politically Speaking: The Pragmatic Analysis of Political Language, Oxford, Blackwell.

WoDAK, R. (1996): Disorders of Discourse, London, Longman.

ZUPNIK, Y. (2002): «A pragmatic analysis of the use of person deixis in political discourse», Journal of Pragmatics, 21(4): 339-383.

\section{Source texts}

CPM Conservative Party Manifesto 2010, [accessed 21 July 2010], $<$ http://www.conservatives.com/Policy/Manifesto.aspx>.

LDPM Liberal Democrat Party Manifesto 2010, [accessed 21 July 2010], $<$ http://www.general-election-2010.co.uk/2010-general-electionmanifestos/Liberal-Democrat-Party-Manifesto-2010.pdf>.

LPM Labour Party Manifesto 2010, [accessed 21 July 2010], $<$ http://www.labour.org.uk/manifesto/>. 